DOI 10.31558/2307-2318.2021.3.4
УДК 330.1(477)
JEL: O10, R10

Бобровська О.Ю.

д. держ. упр., професор, професор кафедри економіки та соціально-трудових відносин, Університет митної справи та фінансів

ORCID: 0000-0002-2174-9040

bobelur@meta.ua

Бикова А.Л.

к. е. н., доцент, завідувач кафедри економіки та соціально-трудових відносин, Університет митної справи та фінансів

ORCID: 0000-0001-7290-9094

bykovaadel@gmail.com

\title{
ФОРМУВАННЯ ЗНАННСВИХ РЕСУРСІВ СИСТЕМИ УПРАВЛІННЯ СОЦІАЛЬНО-ЕКОНОМІЧНИМ РОЗВИТКОМ РЕГІОНІВ
}

Досліджено прочеси формування знаннєвого ресурсу фахівців і керівників системи управління регіонами. Відмічено, щзо в сучасних умовах господарювання, знаннєвий ресурс розглядається як вища џұнність, якість якої з часом не зменшується, а зростає на відміну від усіх інших видів ресурсів, $і$ без якої жоден прочес життєдіяльності в суспільстві не здійснюється. Дослідження зосереджено на знаннєвому ресурсі фахівців і керівників системи управління сочіально-економічним розвитком регіонів, які є базовими адміністративнотериторіальними одинииями, розвиток яких забезпечує розвиток краӥни в иілому. Формування процесів надання знань $і$ організащія їх оволодінням в закладах вищої освіти розглянуто стосовно повноти та відповідності ичих знань потребам управління регіонами й господарюючими суб'єктами їх керованих систем. Потреби $i$ перелік пріоритетних програмних питань щуодо отримуваних знань розглядається за професійною спрямованістю використання знаннєвого ресурсу. Прочес оволодіння ним запропоновано розглядати за етапами, змістом програм, посадових і кваліфікаційних вимог до фахівиів та керівників направлених на управління розвитком регіонів. Розглянуто логістичний ланџюг формування прочесу набуття знань, як знаннєвого ресурсу майбутніх фахівиів $і$ керівників системи управління з урахуванням змісту потреб посадових компетениій, вимог посад, напрямів, програм і планів розвитку керованих систем. Підкреслено необхідність перегляду методології організаиії своєчасної підготовки, перепідготовки і підвищення кваліфікації фахівців шияхом інтегрування теоретичного та практичного контенту навчання. У процесі навчання запропоновано використовувати інновачійні методи навчання, тренінги, майстер-класи із застосуванням інформачійної бази щодо існуючих $i$ майбутніх посад планованого працевлаштування. Визначено вимоги до більш широкого застосування у процесі надання знань можливостей смарт-освіти, технологій бенчмаркетингу, форсайту, методів інновачійних і стратегічних ігор та набуття досвіду командної роботи. Надано пропозииій щзодо подальшого розвитку системи управління знаннями і накопичення знаннєвого ресурсу регіонів, технологій формування й оволодіння методами його використання та засвоєння, представлено в авторській реалізащії иуільової підготовки, перепідготовки й підвищення кваліфікаиії в системі професійного навчання керівників системи управління регіонів.

Ключові слова: знаннєвий ресурс, формування, накопичення, фахівиі, керівники, система управління, соціально-економічний розвиток, регіон, управління знаннями.

Рис. - 1, Літ. -19 
Постановка проблеми. В умовах глобалізації всі розвинуті країни обрали знання як основний чинник розвитку. Освіта стає домінуючим чинником інтелектуалізації суспільства і його розвитку. Вона розглядається як частина інституту освітянської діяльності, що складається із сукупності закладів, організацій, інфраструктури, працівників, теоретико-наукового і методологічного ресурсу, які забезпечують виконання освітянських функцій: навчання, розвитку і соціалізації особистості, формування іiі цінностей і здатностей до інтелектуальної праці. Підготовка фахівців, здатних до створення інновацій для пошуку і засвоєння нових інноваційних рішень 3 метою подальшого розвитку суспільства, є головним завданням вищої освіти. Для цього необхідне впровадження динамічних освітянських програм і застосування гнучких принципів надання знань 3 використанням сучасних технологій, методів навчання i удосконалення організаційних форм. В цьому контексті виникає об'єктивна необхідність постійного аналізу і контролю системи підготовки фахівців 3 повноти, якості і достатності знань, необхідних для розвитку суспільства.

Аналіз останніх досліджень та публікацій. Знання - це перевірений практикою суспільно-історичний, практичний i засвідчений практикою результат підзнання дійсності та адекватне відображення його у свідомості людини у вигляді уявлення понять, суджень і теорії. До поняття «знання» зверталися вчені давнини, грецькі філософи Сократ та Протагор, теоретики постіндустріального суспільства Д Белл, П. Друкер, Е. Тоффлер, П. Портер та ін. [17, с. 28]. Провідні вчені розвинутих країн і українські вчені поняття «знання» досліджували як фактор розвитку, розглядаючи їх як суспільне благо і ресурс економіки, який збільшується, самозростає [18]. Провідні країни світу сформували інноваційну модель суспільного розвитку, яка базується на інтенсивному продукуванні та використанні нових знань, за рахунок втілення яких в технології діяльності, технології організації виробництва продукції, товарів і послуг досягається приріст ВВП від 70 до $80 \%$.

Знаннєвій складовій частині ресурсів належить провідна роль у сфері людських ресурсів. Фундаментом вітчизняних досліджень в сфері людських ресурсів $\epsilon$ роботи С. Бандури, Д. Богині, О. Грішнової, В. Гейця, Т. Заяць, Л. Ільїч, М. Кримової, Е. Лібанової, Л. Лісогор, В. Новікова, О. Новікової, В. Онікієнка, . Петрової, С. Пирожкова, У. Садової, Л. Семів, М. Семикіної та ін. [11; 12; 13; 14; 15; 16].

Освіта починає розглядатись як інвестування в колективне майбутнє суспільства i націй, а не лише майбутній успіх окремої людини. Академік Н. Моісєєв писав «нова цивілізація повинна починатися не з нової економіки, а з нових знань і нових творінь прогресу» [1]. Стає очевидним, що освіту в інтересах розвитку слід сприймати як безперервний процес набуття знань, необхідних для того, щоб розуміти зростання в суспільстві, економіці та соціумі, знаходити оптимальні шляхи вирішення проблем в інтересах зростання можливостей не тільки окремої людини, а й усіх членів суспільства як на найближчу, так і на далеку перспективу. Без формування якісного знаннєвого ресурсу запровадження інноваційних технологій управління розвитком стає неможливим. Тому дослідження можливостей накопичення знань і їх якісного використання повинно стати невідємною частиною процесів управління розвитком в умовах трансформаційних змін у суспільстві.

Мета статті: обгрунтувати комплекс концептуальних положень щодо підвищення уваги до системи побудови організації і змісту знаннєвого ресурсу керованих систем регіонів й можливості його підтримки та накопичення як ресурсу системи управління.

Виклад основного матеріалу. Сучасна парадигма управління будь-якими процесами, об'єктами і явищами характеризується тим, що фокусується на людях і їх 
знаннях, які стають носіями знаннєвого ресурсу. Для забезпечення і підвищення якості і обсягів знаннєвого ресурсу в Україні сформована національна доктрина розвитку освіти, затверджена концепція екологічної освіти та інноваційної освітньої діяльності [2]. Зі складу достатньо великої кількості необхідних заходів стосовно реалізації наданих у процесі децентралізації прав територіальним громадам самостійно вирішувати власні проблеми і більш глибоко та дієво впливати на стан й ефективність плину процесів життєдіяльності, на підпорядкованих територіях, на сучасному етапі і в довгостроковій перспективі, в першу чергу заслуговує на увагу питання підготовки нового типу фахівців та керівників для безпосередньої участі в організації й здійсненні процесів управління, які будуть здатні повністю реалізовувати надані їм повноваження. Перехід територіальних громад до нової стадії і вищої сходинки власного розвитку суттєво залежить від одночасного набуття фахівцями та керівниками сучасних знань й компетенцій до нового типу організації їх діяльності і управління власними справами, а саме: оволодіння сучасними методами виконання самоврядних завдань та функцій суспільного управління.

Бачення нових можливостей підвищення ефективності процесів життєдіяльності керованих систем збільшує увагу до стану використання і відтворення існуючих ресурсів, методів управління, технологій організації, координації, спрямування продуктивних сил на підвищення рівня життя і формування людського капіталу. За даними досліджень інституту економіки та прогнозування України питома вага людського капіталу в галузевій структурі національного багатства в першому десятиріччі XXI ст. становила 46,7 \%, природного $34,8 \%$, виробничого - 12,6\%, а фінансового - 5,8 \%. Це засвідчує, що вказані чинники відіграють основну роль у сталому розвитку країни [3]. Органи влади повинні зосередити свої зусилля на тому, щоб оволодіти знаннями самим і навчити жителів сумісній та раціональній діяльності, використовуючи людські можливості, і тим самим досягти синергізму в спільній роботі.

Як результат творчої розумової діяльності людей знання перетворюють реальність навколишнього середовища в поняття, принципи і закономірності в систему знаннєвих інструментів: теорію, методологію, форми діяльності, взаємовідносини та ін.

Створення умов для отримання, передачі, агрегування й інтегрування знань як бази професійних компетенцій, що включають знаннєвий ресурс, слід розглядати в процесі формування управлінських компетенцій. Цей процес являє собою циклічно повторюваний логістичний ланцюг, який складається 3 низки етапів: I етап - отримання теоретичних і практичних знань у відповідних навчальних закладах; II етап - застосування отриманих знань у процесі управління і визнання їх як головного ресурсу; III етап - отримання результатів здійснюваної управлінської діяльності та їх оцінювання з точки зору дієвості, достатності і якості знань для впливу на розвиток керованих систем; IV - пошук нових джерел поповнення базових знань у процесі їх реалізації як ресурсного потенціалу розвитку; $\mathrm{V}$ - етап поповнення знань та їх творче застосування.

Процеси поповнення знань є постійними, що впливає на потужність цього ресурсу і його постійне якісне оновлення. До чинників підвищення якості цього ресурсу слід віднести: стимулювання приросту знань, забезпечення, зберігання й трансформацію знань, необхідних фахівцям і керівникам систем управління, оцінка знань кожного, нарощування обсягу знань у відповідних підрозділах та загалом, у структурі управління, оцінювання відповідності наявних знань управлінців вимогам знань займаних посад, стимулювання ротації кадрів, ранжування працівників, залучення їх до участі в нових проєктах та інші. У структурі Класифікатора професій ДК 003:2010 [19] професійні назви робіт професій і посад, що займають органи державного управління на всіх рівнях налічують широке коло 
професій фахівців, які здійснюють різноманітні функції представлені відповідно у групах класифікацій професій 1120.1, 1120.2.

Перелік необхідних знань знаходить відображення у функціях і завданнях з управління знаннями, які мають спрямовуватися на створення знаннєвого ресурсу. Розробку інноваційних заходів для постійного безперервного розвитку творчих здібностей управлінських кадрів, підвищення креативності й ефективності застосування знань доцільно здійснювати шляхом складання гнучких каталогів професійних посадових обов'язків i завдань за існуючими посадами, критеріїв якості їх виконання 3 урахуванням ретроспективних складових результатів діяльності та оцінювання творчого потенціалу й наявних умов для його реалізації в майбутньому.

Необхідна вичерпна інформація про те, якими саме професійними знаннями мають володіти фахівці і керівники системи управління, займаючи відповідні посади, яка структура знань та навичок за змістом й технологічними методами потрібна на їх теперішніх посадах і в майбутньому. Запровадження у зміст функціональної діяльності керівників функції управління знаннєвим ресурсом стане ще одним потужним джерелом підвищення ефективності діяльності органів влади на територіях.

Теоретичні та практичні засади базової професійної підготовки фахівців у вищих навчальних закладах створюють лише первісний знаннєвий ресурс фахівців для їх особистого професійно-компетентнісного розвитку i майстерності, які для кінцевого становлення й повної самореалізації повинні активно поповнюватись та оновлюватись протягом усього їх життя.

Потреби суспільства, які стрімко розвиваються, призводять до старіння набутої професійної освіти і компетенцій. Для багатьох професій упродовж багатьох років ці компетенції зменшуються на 50 \%. Кожні 72 години, за підрахунками вчених, відбувається подвоєння інформації, і тому велика частина освітнього контенту відстає від застосовуваних технологій на $2-3$ покоління [5].

Керівник, зорієнтований на сучасний і майбутній розвиток, повинен мати глибоке та нестандартне мислення, потужний інтелектуальний й духовний потенціал, талант спілкування з оточенням і здатність до збереження довкілля.

Єдину модель (портрет) сучасного фахівця системи управління в динамічно змінюваному середовищі існування будь-якої сфери життєдіяльності та на будь-якому ієрархічному рівні створити майже неможливо і навіть безперспективно. Необхідно постійно зосереджувати увагу на поновленні і розширенні професійних компетенцій майбутніх та працюючих фахівців з напряму «розвиток територій». Це стосується не лише змісту виконуваних завдань, а й методів діяльності на займаних посадах. Важливе значення має і набуття таких властивостей, як швидкість, організованість, вміння застосовувати міжпредметні зв'язки, володіння творчим, а не тільки продуктивним мисленням, наявність та розвиток критичного мислення.

Критичне мислення - це мислення, що характеризується: здатністю формулювати питання i знаходити відповіді; умінням аналізувати інформацію i знаходити суперечності в ній; наявністю власної точки зору з певного питання і відстоюванням іiі, використовуючи переконливі докази; умінням обгрунтовувати твердження i застосовувати отримані результати [6, с. 52].

На думку вчених Південної Кореї, критичне мислення належить до семи умінь XXI ст., у складі яких виділяють критичне мислення та розв'язання проблем, творчість та інновації, співпраця та лідерство, міжкультурне взаєморозуміння, комунікація, грамотність у сфері інформаційно-комунікативних технологій, кар'єра та життєві навички [7, с. 22].

Саме до підготовки таких фахівців в останні роки була прикута увага прогресивних 
країн. Сьогодні вона починає поглиблюватися і розширюватися в Україні на всіх ієрархічних рівнях життя - країни, регіонах, містах, селищах. Формування й використання інноваційних підходів і технологій поповнення й оновлення професійних знань, навичок та компетентностей стає невід'ємною, надзвичайно важливою і пріоритетною складовою стратегій та планів розвитку, а також пов'язаних з ними нових аспектів функцій органів влади, отриманих в результаті децентралізації.

Сучасні вимоги до фахівців, на яких покладається системне виконання функцій управління, повинні виявлятися шляхом ідентифікації визначених посадових обов'язків iз завданнями розвитку, а також із системою світоглядних і професійних позицій, переконань, знань, навичок та компетенцій, креативністю під час генерування ідей і їх реалізації, компетентності ініціювати й розробляти заходи для розвитку відповідно ноосферній концепції, здатність працювати у великих групах.

Технології реалізації управлінських функцій і завдань, крім забезпечення їх оновленого змісту та послідовності реалізації в управлінському циклі потребують від їх виконавців «інтегральної» компетентності для досягнення поставлених цілей й завдань, узгодження дій щодо «вертикалі» і «горизонталі» управлінської ієрархії, наявності у фахівців глибоких суміжних знань, комунікативної та професійної мобільності, адаптивної спроможності до протистояння викликам навколишнього середовища. Зазначене вимагає постійного системного контролю та, за необхідності, перегляду підходів до вибору цілей і змісту підготовки, перепідготовки та підвищення кваліфікації фахівців управлінського корпусу, а для деяких груп фахівців - розширених еволюційних та революційних змін у цій системі.

В Україні створена потужна система організацій, в яких підвищують кваліфікацію, проходять підготовку та перепідготовку фахівці і керівники системи управління органів влади. Аспекти формування змісту, технологій і інструментарію їх професійного навчання мають досить міцну методологічну базу. Широко застосовуються технології дистанційного навчання (веб-навчання, форуми, чати, відеоконференції та інші засоби інформаційнотехнічного, технологічного та програмно-прикладного сервісу). Однак короткі строки підготовки і проходження перепідготовки практиків без відриву від виконуваної діяльності знижують обсяг та якість знань, які їм надаються. Необхідним є подальший пошук шляхів інтенсивності підвищення якості рівня професійної освіченості, компетентності й вільне володіння (на рівні користувача) програмними продуктами Microsoft Office. Саме підвищення посадових компетенцій стосовно виконання не тільки поточних службових обов'язків і здійснення покладених на них повноважень на стратегічному рівні в системі вищого професійного навчання набувають особливого значення.

Для забезпечення розвитку суспільства необхідним стає систематичне доповнення існуючих форм організації навчання інтегрованою формою, спрямованою на поповнення знань, компетенцій та навичок з огляду на виконання функцій соціально-економічного розвитку і пов'язаних з ними вирішуваних завдань, удосконалення здійснення службових комунікативних зв'язків, технологій партнерського спілкування і корпоративної культури з використанням інформаційно-комп'ютерних технологій.

Необхідним стає підвищення адаптаційних здібностей керівників i фахівців профільних підрозділів системи управління. Зазначене формує нові освітні потреби, необхідність своєчасного і поглибленого опанування нового нормативно-законодавчого, методологічного та інституційно-організаційного забезпечення вирішуваних завдань у динамічно змінюваному навколишньому середовищі. Ключову роль у діяльності керівників і фахівців системи управління органів влади починають відігравати нові форми самоосвіти, саморозвитку, самоорганізації для регулювання процесів життєдіяльності 
населення на підпорядкованих територіях не тільки в сьогоденні, а й у майбутньому, питання стратегічного прогнозування, планування і створення умов та засад стійкого розвитку, що мотивує до активного набуття нових знань.

Стрижнем такої освіти стало запровадження інноваційних технологій i організаційних форм навчання. У їх складі перш за все виокремлюється електронне і дистанційне навчання як складова концепції smart-освіти. Вона передбачає створення інтелектуального середовища для широкої доступності знань і безперервного розвитку компетенцій учасників освітнього процесу на основі нових технологій.

Термін «smart» англійського походження, який перекладається як розумний, інтелектуальний. Тлумачення абревіатури «smart» надав В. Тихоміров, а саме: S самокерований, М - мотивований, A - адаптований, $\mathrm{R}$ - ресурсозабезпечений, T технологічний [8]. Інструментами технологій smart-освіта стали застосовувані в освітніх цілях смартфони, планшети, інтегровані й інтерактивні дошки, smart-борди та інші пристрої із доступом до мережі Інтернет різноманітних навчальних програм, аудіо- i відеолекцій, відеоконференцій, семінарів, відеокурсів тощо, які стають усе більш популярними і затребуваними. Їх доступність забезпечується завдяки сервісам Google, програмами комплексу Microsoft Office, комплексами управління економічною діяльністю і користування електронною бібліотекою. Ідея smart-освіти стала підгрунтям ідеї створення smart-суспільства, smart-країни, smart-регіону, smart-міста, smart-людини.

Перехід на smart-освіту став провідною стратегією високорозвинених країн світу США, Південної Кореї, Японії та європейських держав. У 2015 р. їх провідними освітніми центрами стали: Барселона, Нью-Йорк, Лондон, Ніцца, Сінгапур, Париж, Копенгаген, Відень [7, с. 22].

Прогнозуючи майбутні результати впливу smart-освіти на розвиток суспільства, світовий банк визначив прогнозну структуру національного багатства для країн i3 smartсуспільством. Вона буде складатися на $5 \%$ із природних ресурсів, на $18 \%$ із виробничого капіталу та на $77 \%$ із знань, умінь людини [9, с. 30].

Для розвитку smart-освіти в Україні центральним питанням стало широке запровадження дистанційного навчання шляхом розвитку онлайн-освіти. I хоч перший крок у цьому напрямі вже здійснений, поки залишається проблема підготовки кадрів викладачів, які здатні працювати по-новому, володіти навичками роботи в соціальних мережах у світі мережевих професійних спільнот, використовуючи сучасні технології сервісу i інтернет-ресурсів, формування програм онлайн-освіти, створення методологічного апарату й практичного супроводу інтерактивного, дистанційного та інклюзивного навчання.

Особливістю професійної перепідготовки й підвищення кваліфікації стає глибоке засвоєння творчого використання інформаційно-комп'ютерних технологій при підготовці і реалізації управлінських рішень не тільки для вирішення поточних інформаційно-облікових завдань, а й для вирішення стратегічних та перспективних питань, своєчасного й ефективного здійснення корегуючих і регулюючих дій. Необхідним стає запровадження прогресивних методів самоврядування із досвіду зарубіжних розвинутих країн та інші дії, до яких спонукають виклики трансформаційних процесів у суспільстві.

Сучасний стан, рівень розвитку і можливості інформаційно-комп'ютерних технологій дозволяють своєчасно приймати обгрунтовані рішення завдяки наявності широкого переліку програмного забезпечення, надають можливість аналізувати не лише кількісні параметри та показники керованих процесів і об'єктів, а й закономірності розвитку економічних, соціальних чи інших явищ та систем за принципом «причина - наслідки», робити прогнозні припущення, здійснювати імітаційне моделювання, не проводячи 
складних попередніх експериментів. Для їх опанування і творчого застосування в системі управління необхідне розуміння сутності та напрямів змін навколишнього середовища й обов'язковість урахування екологічного імперативу. При формуванні стратегічних цілей і завдань суспільного розвитку слід враховувати ключові чинники впливу на його генетику, системно інтегруючи ці знання в практику господарювання.

В Україні в умовах суттєвих ресурсних та бюджетних обмежень для прогнозування майбутнім фахівцям необхідно володіти технологіями бенчмаркінгу, соціальноекономічного форсайту та інших ефективних методів і інструментів, які здатні забезпечити ефективне управління трансформацією керованих систем з урахуванням інтересів як жителів регіонів, так і держави.

Системні якісні зміни у змісті навчальних програм підвищення кваліфікації, підготовки та перепідготовки фахівців та керівників системи управління орієнтовані не тільки на продуктивне засвоєння інноваційних знань, а й на набуття широких компетенцій в інноватиці. Це може бути досягнуто за рахунок об'єднуючого підходу до технології оновлення знань практиків, а саме організації підвищення їх компетентностей за пропонованою системною моделлю (рис. 1).

Планування потреб і вимог до змісту і обсягів перепідготовки фахівців, які безпосередньо задіяні в процесах управління, повинно здійснюватись покроково:

- визначення завдань і функцій управління в процесі розвитку керованих систем 3 урахуванням особливостей територій, які визначають об'єктивні потреби до змісту знань і посадових компетенцій для їх органів управління та мотивують вимоги до фахівців, які можуть займати ці посади;

- аналіз, оцінка відповідностей і розбіжностей знань і компетенцій фахівців, які займають існуючі посади, 3 потребами сьогодення і майбутнього, для досягнення поставлених стратегічних цілей;

- формулювання вимог до напрямів та змісту програм і планів підготовки, перепідготовки й підвищення кваліфікації державних службовців для підвищення знаннєвого ресурсу і його якості.

Наступний етап - організація інтегрованого процесу формування знаннєвого ресурсу, який гарантуватиме перепідготовку і підвищення кваліфікації керівників та фахівців, здійснюючи узгодження пріоритетних питань підвищення професійних компетенцій відповідно до стратегій розвитку й врахування чинників впливу на трансформаційні процеси в суспільстві і в освіті. Це доволяє створити умови для забезпечення вимог до змісту освіти і рівня опанування їі основ в процесі навчання. На цьому етапі укріплюється співпраця і розвивається партнерство органів влади, підприємств (організацій) й закладів вищої освіти 3 метою підвищення конкурентоспроможності освіти, що надається. Далі здійснюється перегляд розробленої чи створюванної новоствореної методології організації перепідготовки і підвищення кваліфікації з використанням новітніх освітянських технологій. 


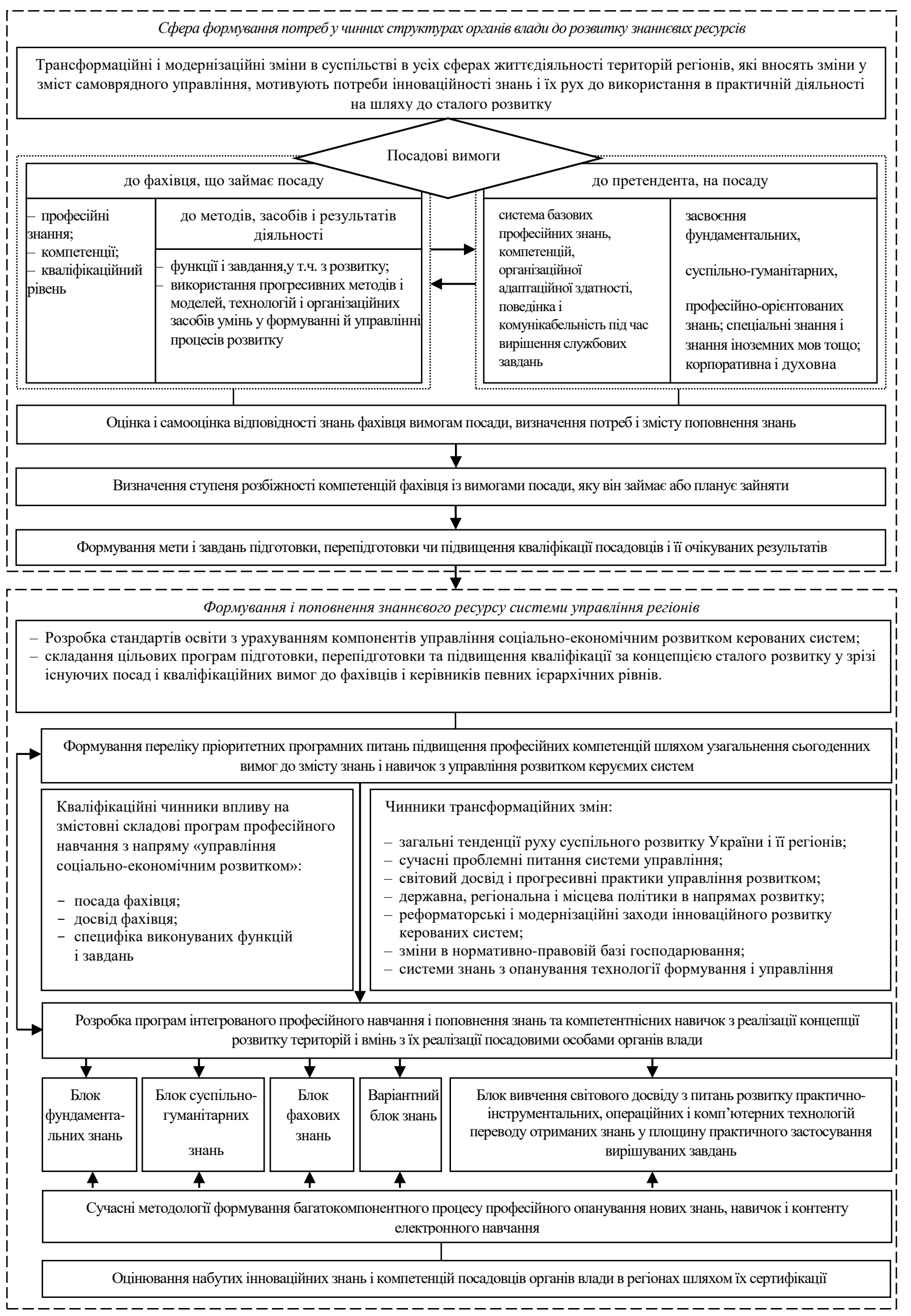

Рисунок 1. Модель реалізації цільової підготовки, перепідготовки і підвищення кваліфікації в системі професійного навчання керівників системи управління регіонів 
Модель передбачає досягнення результату шляхом участі у тренінгах і майстеркласах для оновлення знань не за окремими напрямами знань, які надаються у відокремлених модулях, а в їх «горизонтальній» площині: за змістом виконуваних конкретних посадових функцій і завдань спрямованих на включення їх у побудову соціально орієнтованих інноваційних процесів розвитку за принципами: громада - регіон - країна, людина - суспільство.

Теоретичні заняття i технології їх проведення концентрують у собі взаємодоповнювальну та сумісно використовувану систему знань різних наук, яку необхідно мати на тій чи іншій посаді. Наприклад, знання статистики і математики, планування і прогнозування, фіскальної політики, методів бенчмаркінгу, SWOT-аналізу, маркетингових стратегічних досліджень, логістики, соціології та ін. Їх комбінація буде залежати від поставленої мети і змісту вирішуваних проблемних питань функціональних і міжфункціональних завдань, комунікацій і відносин партнерства.

У програмах навчання i перепідготовки фахівців та працівників щодо застосування їх компетенцій в процесах сталого розвитку, побудованих на основі інноваційних технологій, вважаємо, слід застосовувати відомі, ефективні, але недостатньо використовувані методи проведення інноваційних і стратегічних ігор [4].

Метод інноваційних ігор був запропонований В.С. Дудченко в 1981 p. для підготовки керівників, здатних розробляти стратегії переходу галузей на госпрозрахунковий метод господарювання. Загальним принципом інноваційних ігор було колективне вирішення "розмитих», чітко не сформульованих завдань і розробка непередбачуваних інноваційних продуктів. Гра «розгорталась» як цілісна системна діяльність: колективне уточнення i формулювання проблеми, колективні рішення, самопрограмування, конкурентність, змагання груп тощо. Особливістю гри є використання принципу «навчання, яке розвиває», що передбачає не розширення обсягів знань, а розвиток умінь щодо застосування набутих знань для пошуку нових рішень, залучаючи при цьому власні творчі здібності. Для вивчення великого обсягу інформації необхідно створити належне інформаційно-аналітичне середовище, умови мотивації до використання нового способу господарювання і розуміння його економічних можливостей. Гра триває від 5 до 10 днів, для цього організовується 3 групи учасників кількістю по 9 - 10 осіб.

Особливої уваги заслуговують і стратегічні ігри. Це конфліктні ігри, в яких ефективність рішення, яке приймає один учасник, залежить від дій інших учасників. Конфліктні ситуації виникають при зіткненні інтересів двох або більше учасників ігор. Стратегія гри визначається як система поведінки ії учасників за умови, що кожний учасник має у своєму розпорядженні безкінечну кількість стратегій.

При перегляді програм підвищення кваліфікації необхідно закладати для їх опанування можливості вивчення різноманітності наукових підходів і визначення системного характеру процесів розвитку з метою відображення в них надаваних знань, полі- і міждисциплінарності та забезпечення послідовності їх викладання. Це дозволить керівникам і фахівцям багатоаспектно уявляти проблемне поле управлінської діяльності, методи і принципи тї сучасного професійного забезпечення.

Широта та багатоаспектність завдань посадових обов'язків, закладених у ділові ігри, практичні тренінги і майстер-класи, повинна розроблятися на основі статистичних, поточних та звітних даних керованих слухачами систем, процесів та об'єктів управлінської діяльності. Вони відображають наявні тенденції й проблеми стану і розвитку керованих систем, що дозволяє суттєво поглибити практичну спрямованість та ефективність підвищення кваліфікації. Особливістю всіх видів занять повинно стати проведення їх за командним принципом. Команди формуються із профільних фахівців, 
провідних спеціалістів, начальників структурних підрозділів, що підвищує їх комунікативні здатності, рольове призначення і змінює управлінське мислення й уявлення про власну участь та відповідальність за спільні результати діяльності підпорядкованих ланок.

Для опанування технологій запобігання появи нових проблем і їх вирішення, при проведенні занять, необхідним є створення не тільки «типових», а й неординарних сценарних алгоритмів, які формують упереджувальне мислення та технології управлінської праці для відповідного професійного спрямування. Вони повинні акумулювати знання ряду навчальних дисциплін, новітніх технологій і системоутворюючої інформації, що створює підгрунтя для передбачення та упередження антикризових дій.

У процесі тренінгових занять слухачі поглиблюють знання із суспільних наук, теоретичні, методологічні, інформативно-законодавчі знання з регіональної економіки, регіональної політики, бюджетного менеджменту, маркетингу, стратегічного управління, статистики і економетрії. Обов'язковим є поглиблення знань з інформаційних технологій i навичок роботи 3 комп'ютерною технікою, опанування відповідних програмноприкладних продуктів. Окремої уваги заслуговує підвищення досвіду командної роботи, вміння ліквідувати порушення збалансованості і відхилення в плині процесів діяльності, оперативно налагоджувати комунікативні зв'язки, своєчасно обмінюватись інформацією, думками, висновками тощо. Така організація підвищення кваліфікації керівників i фахівців здатна наповнити цей процес сучасним загальнонауковим, концептуальним та системно-синергетичним змістом ноосферної концепції розвитку суспільства, погодженої із сучасними проблемами розвитку територій.

Розглядаючи знаннєвий ресурс керівників і фахівців системи управління, слід звертати увагу на ступінь соціальної зрілості керівників, засвоєння ними знань, ціннісних орієнтацій та інтересів, ставлення до праці, запити у сфері праці, виходячи з ієрархії потреб, від яких залежить трудовий ресурс працюючих й їх здатність до накопичення професійних, організаційних і управлінських знань. Зміст і вимоги до підвищення соціальної компоненти знань відображаються в погоджених програмах підвищення кваліфікації, а набуття нових знань оцінюється за результатом оцінки опанування знань після проходження навчання.

Підтвердження набутих знань і компетенцій керівників, які займають відповідні посади, здійснюється шляхом оцінювання набутих знань та видачі їм сертифікатів.

Використовуючи пропозицію українських вчених стосовно системи стимулювання зростання освітньо-кваліфікаційного рівня працівників з урахуванням підвищення рівня компетенцій у процесі підвищення кваліфікації [10, с. 312], доцільно започаткувати метод встановлення їх персонального рейтингу, шляхом ранжування працівників за загальною оцінкою їх знаннєвого ресурсу за коефіцієнтами:

- відповідність освіти (рівень освіти) змісту виконуваних функцій (Ко);

- рівень досвіду роботи (стажу роботи) у сфері діяльності (Кд);

- рівень набутих компетенцій у процесі підвищення кваліфікації і вміння застосовувати їх для втілення виконуваних та нових справ $\left(К_{K}\right)$ :

$$
\mathrm{Pe}=\mathrm{K}_{\mathrm{O}} * \mathrm{~K}_{\mathrm{д}} * \mathrm{~K}_{\mathrm{K}}
$$

де $0,8 \leq \mathrm{K}_{\mathrm{O}} \leq 2$ - зростає пропорційно поглибленню знань працівника, до базового рівня освіти $(0,8)$ додавати 0,2 при проходження підвищення кваліфікації на займаній посаді;

$2 \leq \mathrm{K}_{\text {д }} \leq 4,5$ - за перші шість років стажу приріст коефіцієнта дорівнює 0,8 , а в наступні роки додавати по 0,02 за кожен відпрацьований рік;

КК - вміння працівника втілювати в конкретні справи знання i досвід. Обчислюється додаванням 0,1 до базового коефіцієнта за участь у кожному проєкті, для 
працівника дорівнює кваліфікаційному розряду.

Залежно від місця працівника в системі рейтингового оцінювання доцільно формувати кадрові резерви.

Висновки. Сьогодні вища освіта функціонує в умовах ринкових відносин. Набуття професійних знань здійснюється переважно на комерційній умові. Прослідковується чітка тенденція до постійного зростання питомої ваги здобувачів освіти, що навчаються за рахунок коштів фізичних та юридичних осіб у загальному обсязі та порівняно зі здобувачами, що навчаються за рахунок коштів державного бюджету. 3'явились і нові інтеграційні форми освіти, більш диференційованими стали іiї функції.

Професійні знання як інтелектуальний ресурс соціально-економічного зростання країни вимагають нових підходів до їх систематизації, осмислення, методів опанування і трансформації їх імплементації в практичну діяльність. Особливої уваги заслуговують процеси опанування знаннями при підготовці і підвищенні кваліфікації керівників і фахівців багатовекторних і складних керованих систем управління в просторі регіонів.

При побудові моделей освіти фахівців і керівників системи управління постає необхідність широкого застосування їх більш глибокої практичної підготовки. Потребується унормування змісту і зміцнення взаємовідносин, взаємодії і партнерства органів влади i суб'єктів господарювання регіонів із закладами вищої освіти підготовки фахівців і керівників і подальшого підвищення їх кваліфікації за взаємоузгодженими програмами навчання, реальними темами дипломних і магістерських робіт, що виконуються за реальними даними структурних підрозділів органів влади, спрямовуємих на розширення «вузьких місць» і вирішення функціональних завдань на майбутніх робочих місцях. Важливим є забезпечення кількісної і якісної збалансованості потреб регіону в підготовці, перепідготовці і підвищенні кваліфікації фахівців та керівників керованих систем й суб'єктів господарювання підвладних територій та плануємих обсягів їх підготовки і перепідготовки в закладах вищої освіти.

Дієвою підтримкою наведених заходів може стати створення регіонального фонду розбудови економіки знань, кошти якого необхідно спрямовувати на створення регіональної системи смарт-управління, використання сучасних інформаційних технологій, шляхом обєднання інтересів органів влади, суб'єктів господарювання і закладів вищої освіти, розташованих на території регіонів.

Щоб не накопичувати невідворотність постійного системного вирішення проблеми конкурентоспроможності підвищення економіки регіонів за рахунок нестачі висококваліфікованих фахівців і керівників для попередження стрімкого зростання безробіття на території регіону при відсутності чи зниженні темпів економічного розвитку доцільним $\epsilon$ розробка Регіональної політики формування, використання, розвитку відтворення i накопичення знаннєвих ресурсів як підгрунтя і головного чинника інноваційної економіки знань та нового технологічного рівня господарювання.

До подальших напрямів дослідження проблеми підвищення обсягів освітніх ресурсів, як підгрунтя економіки знань в регіонах, доцільно віднести розробку мотиваційних механізмів створення комплексних систем управління знаннями, об'єднуючих зусилля та інтереси органів влади й закладів вищої освіти, які забезпечують підготовку фахівців і керівників органів влади та органів галузевого управління з метою створення умов переходу регіонів на смарт-спеціалізацію, підвищення якості життя населення. Для проєктування моделей перебудови організації вищої освіти і побудови оновлених організаційних схем ії здійснення доцільно дослідження можливостей розширення діапазону набуття професійних знань та навичок при отриманні дуальної освіти для набуття швидкої адаптації діяльності фахівців і керівників в системі управління до нових умов. 


\section{СПИСОК ВИКОРИСТАНИХ ДЖЕРЕЛ}

1. Моисеев Н. Н. Быть или не быть... человечеству?: монография. Москва: ГУП ИПК «Ульяновский Дом печати», 1999. 288 с.

2. Національна парадигма сталого розвитку України; за заг. ред. Б. Є. Патона. Київ: Державна установа «Інститут економіки природокористування та сталого розвитку Національної академії наук України», 2012. 72 с.

3. Капіталізація економіки України / за ред. В. М. Гейця, А. А. Гриценка. Київ: Ін-т екон. та прогнозування, 2007. 220 с.

4. Вертакова Ю. В., Симоненко Е. С. Управление инновациями: теория и практика: учеб. пособие. Москва: Эскимо, 2008. 432 с. (Высшее экономическое образование).

5. Дзюба Т. Талалай В. Smart-освіта - розвиток сучасності // Smart-освіта: ресурси та перспективи: матеріали II Міжнар. наук.-метод. конф. (Київ, 23 лист. 2016). Київ : Київ. нац. торг.-екон. ун-т, 2016. С. 34 - 37.

6. Тимоха С. Теоретичні основи розвитку критичного мислення студентів // Гуманізація навчально-виховного процесу. Вип. IV. Ч. ІІ. Слов'янськ, 2011. С. 51 - 58.

7. Богатирьова К. Безперервна освіта - ознака Smart-суспільства // Smart-освіта: ресурси та перспективи : матеріали II Міжнар. наук.-метод. конф., Київ, 23 листоп. 2016 p. Київ : Київ. нац. торг.-екон. ун-т, 2016. С. $22-23$.

8. Тихомиров В. П. Мир на пути к smart education. Новые возможности для развития // Открытое образование. 2011. № 3. С. 22 - 28.

9. Волосович С. Пріоритетні складові старт-освіти в умовах суспільних трансформацій // Smart-освіта: ресурси та перспективи : матеріали II Міжнар. наук.метод. конф. (Київ, 23 лист. 2016). Київ : Київ. нац. торг.-екон. ун-т, 2016. С. 30 - 32.

10. Стадник В. В., Йохна М. А. Інноваційний менеджмент: навч. посіб. Київ : Академвидат, 2006. 464 с.

11. Бандур С. І. Стратегічні імперативи розвитку трудового потенціалу України // Ринок праці та зайнятість населення. 2013. № 1. С. 5 - 9.

12. Геєць В. М. Бар'єри на шляху розвитку промисловості на інноваційній основі та можливості їх подолання // Економіка України. 2015. № 1. С. 4 - 25.

13. Заяць Т. А. Розвиток регіонального освітнього менеджменту в контексті глобальних імперативів // Економіка і регіон. 2013. № 2. С. 16 - 20.

14. ІІлїч Л. М. Взаємодія ринків праці та освіти: сутність, характерні риси та модель функціонування // Економіка та держава. 2017. № 4. С. 69 - 74.

15. Кримова М. О. Оцінка конкурентоспроможності молодих фахівців з економічною освітою на ринку праці України // Демографія та соціальна економіка. 2015. № 2. С. 53 64.

16. Лісогор Л. С. Освітні чинники забезпечення інноваційного людського розвитку // Науковий вісник Полтавського університету споживчої кооперації України. 2008. № 3(30). С. $421-424$.

17. Гузар У. Є. Економіка знань та її перспективи для України // Регіональна економіка. 2009. № 1. С. $27-35$.

18. Рак Н. Є. Економіка знань: сутність та фактори управління знаннями // Регіональна економіка. 2009. № 3. С. $224-232$.

19. Класифікатор професій ДК 003:2010: Наказ Держспоживстандарту України від 28 липня 2010 р. № 327. Режим доступу: https://zakon.rada.gov.ua/rada/show/va327609-10\#Text. 


\section{REFERENCES}

1. Moiseev, N. N. (1999) Byt ili ne byt... chelovechestvu? [To be or not to be ... to humanity?]. Moskva: GUP IPK «Ulyanovskiy Dom pechati». (in Russian)

2. Paton, B. Ye. (ed.) (2012) Nacional`na parady`gma stalogo rozvy`tku Ukrayiny [National paradigm of sustainable development of Ukraine]. Ky yiv: Derzhavna ustanova «Insty`tut ekonomiky` pry`rodokory`stuvannya ta stalogo rozvy`tku Nacional`noyi akademiyi nauk Ukrayiny». (in Ukrainian)

3. Gejcya, V. M., \& Gry`cenka, A. A. (2007) Kapitalizaciya ekonomiky` Ukrayiny` [Capitalization of Ukraine's economy]. Ky`yiv: In-t ekon. ta prognozuvannya. (in Ukrainian)

4. Vertakova, Yu. V., \& Simonenko, Ye. S. (2008) Upravlenie innovatsiyami: teoriya i praktika [Innovation management: theory and practice]. Moskva: Eskimo. (in Russian)

5. Dzyuba, T., \& Talalaj, V (2016) Smart-osvita - rozvy` tok suchasnosti [Smart-education - the development of modernity]. Proceedings of the Smart-osvita: resursy' ta perspekty 'vy' (Ukrainian, Ky`yiv, 23 ly`st, 2016), Ky`yiv: Ky`yiv. nacz. torg.-ekon. un-t, pp. $34-37$.

6. Ty`moxa, S. (2011) Teorety`chni osnovy` rozvy`tku kry`ty`chnogo my`slennya studentiv [Theoretical bases of development of critical thinking of students]. Gumanizaciya navchal'no-vy`xovnogo procesu. vol. IV. no. II. pp. $51-58$.

7. Bogaty`r`ova, K. (2016) Bezperervna osvita - oznaka Smart-suspil`stva / Katery`na Bogaty'r'ova [Continuing education is a sign of a smart society]. Proceedings of the Smartosvita: resursy` ta perspekty`vy' (Ukrainian, Ky`yiv, 23 ly`st, 2016), Ky`yiv: Ky`yiv. nacz. torg.-ekon. un-t, pp. $22-23$.

8. Tikhomirov, V. P. (2011) Mir na puti k smart education. Novye vozmozhnosti dlya razvitiya [The world on the way to smart education. New opportunities for development]. Otkrytoe obrazovanie, no. 3. pp. $22-28$.

9. Volosovy`ch, S. (2016) Priory`tetni skladovi start-osvity` v umovax suspil`ny`x transformacij [Priority components of start-up education in the conditions of social transformations]. Proceedings of the Smart-osvita: resursy` ta perspekty vy` (Ukrainian, Ky`yiv, 23 ly`st, 2016), Ky`yiv: Ky`yiv. nacz. torg.-ekon. un-t, pp. 30 - 32.

10. Stadny`k, V. V., \& Joxna, M. A. (2006) Innovacijny`j menedzhment [Innovation management]. Ky`yiv: Akademvy`dat. (in Ukrainian)

11. Bandur, S. I. (2013) Strategichni imperaty`vy` rozvy tku trudovogo potencialu Ukrayiny [Strategic imperatives for the development of Ukraine's labor potential]. Ry`nok praci ta zajnyatist naselennya, no. 1. pp. 5 - 9 .

12. Geyecz', V.M. (2015) Bar'yery` na shlyaxu rozvy`tku promy`slovosti na innovacijnij osnovi ta mozhly`vosti yix podolannya [Barriers to the development of industry on an innovative basis and opportunities to overcome them]. Ekonomika Ukrayiny`, no. 1.pp. 4-25.

13. Zayacz, T. A. Rozvy`tok regional`nogo osvitn`ogo menedzhmentu v konteksti global`ny`x imperaty`viv [Development of regional educational management in the context of global imperatives]. Ekonomika i region, no. 2. pp. 16 - 20.

14. Il'yich, L. M. (2017) Vzayemodiya ry`nkiv praci ta osvity`: sutnist`, xarakterni ry`sy` ta model funkcionuvannya [Interaction of labor and education markets: essence, characteristics and model of functioning]. Ekonomika ta derzhava, no. 4. pp. $69-74$.

15. Kry`mova, M. O. (2015) Ocinka konkurentospromozhnosti molody`x faxivciv $\mathrm{z}$ ekonomichnoyu osvitoyu na ry`nku praci Ukrayiny` [Assessment of the competitiveness of young professionals with economic education in the labor market of Ukraine]. Demografiya ta social'na ekonomika, no. 2. pp. $53-64$.

16. Lisogor, L. S. (2008) Osvitni chy`nny`ky`zabezpechennya innovacijnogo lyuds`kogo rozvy`tku [Educational factors to ensure innovative human development]. Naukovy`j visny`k 
Poltavs `kogo universy`tetu spozhy`vchoyi kooperaciyi Ukrayiny`, no. 3(30). pp. 421 - 424. 17. Guzar, U. Ye. (2009) Ekonomika znan` ta yiyi perspekty`vy` dlya Ukrayiny` [Knowledge economy and its prospects for Ukraine]. Regional na ekonomika, no. 1. pp. 27 - 35.

18. Rak, N. Ye. (2009) Ekonomika znan`: sutnist' ta faktory upravlinnya znannyamy' [Knowledge economy: essence and factors of knowledge management]. Regional 'na ekonomika, no. 3. pp. $224-232$.

19. Klasy`fikator profesij DK 003:2010: Nakaz Derzhspozhy`vstandartu Ukrayiny` vid 28 ly`pnya 2010 r. \# 327. Retrieved from https://zakon.rada.gov.ua/rada/show/va327609-10\#Text.

\section{Бобровская Е.Ю., Быкова А.Л. \\ ФОРМИРОВАНИЕ ЗНАНИЕВЫХ РЕСУРСОВ СИСТЕМЫ УПРАВЛЕНИЯ СОЦИАЛЬНО- ЭКОНОМИЧЕСКИМ РАЗВИТИЕМ РЕГИОНОВ}

Исследованы процессы формирования знаниевого ресурса специалистов и руководителей системы управления регионами. Отмечено, что в современных условиях хозяйствования, знаниевый ресурс рассматривается как высшая ценность, качество которой со временем не уменьшается, а растет в отличии от всех видов ресурсов, и без которой ни один процесс жизнедеятельности в обществе не осуществляется. Исследование сосредоточено на знаниевом ресурсе спечиалистов и руководителей системы управления социально-экономическим развитием регионов, которые являются базовыми административно-территориальными единицами, а их развитие обеспечивает развитие страны в целом. Формирование прочессов предоставления знаний и организация их овладением в выстих учебных заведениях рассмотрены относительно их полноты и соответствия потребностям управления регионами, субъектами хозяйствования и управляемых ими систем. Потребности и перечень приоритетных программных вопросов относительно получаемых знаний рассматривается в соответствии с профессиональной направленностью использования знаниевого ресурса. Процесс овладения им предложено рассматривать по этапам, содержсанию програм, должностных и квалификационных требований $\kappa$ специалистам и руководителям по управлению развитием регионов. Рассмотрена логистическая иепь формирования процесса получения знаний, как знаниевого ресурса будущих специалистов и руководителей системы управления с учетом содержания потребностей к должностным компетениям, требований занимаемым должсностям, направлений, программ и планов развития управляемых систем. Подчеркнута необходимость пересмотра методологии организачии подготовки, переподготовки и повыпения квалификации путем интегрирования теоретического и практического контента обучения. В процессе обучения предложено использовать инновационные методы обучения, тренинги, мастер-классы с применением информационной базы для сущуествующих и будущих должностей планируемого трудоустройства. Определень требования к более широкому применению в процессе предоставления знаний возможностей смарт-образования, технологий бенчмаркетинга, форсайта, методов инновачионных и стратегических игр и приобретения опыта командной работы. Представлены предложения по дальнейшему развитию системь управления знаниями и накоплению знаниевого ресурса регионов, технология его формирования, овладения методами его использования и усвоения представлена в авторской модели реализачии целевой подготовки, переподготовки и повышения квалификации в системе профессионального обучения руководителей системы управления регионов.

Ключевые слова: знаниевый ресурс, формирование, накопление, специалисты, руководители, система управления, сочиально-экономическое развитие, регион, управление знаниями.

\section{O. Bobrovska, A. Bykova \\ ORMATION OF KNOWLEDGE RESOURCES OF THE SYSTEM OF SOCIO-ECONOMIC DEVELOPMENT MANAGEMENT OF REGIONS}

The processes of formation of knowledge resource of specialists and managers of the regional management system are investigated. It is noted that in modern economic conditions, the knowledge resource is considered as the highest value, the quality of which does not decrease over time, but increases unlike all other types of resources, and without which no process of life in society is not carried out. The research focuses on the knowledge resource of specialists and managers of the management system of socio-economic development of the regions, which are the basic administrative-territorial units, the development of which ensures the development of the country as a whole. The formation of knowledge transfer processes and the organization of their mastery in higher education institutions are considered in relation to the completeness and compliance of this knowledge with the needs of regional management and economic entities of their managed systems. The needs and the list of priority program questions concerning the received knowledge are considered on a professional orientation of use of a knowledge resource. It is proposed to consider the process of mastering it by stages, content of programs, job and qualification requirements for specialists and managers to manage the development of regions. The logistic chain of formation of the process of knowledge acquisition as a knowledge resource of future specialists and 
managers of the management system is considered taking into account the content of needs of job competencies, requirements of positions, directions, programs and development plans of managed systems. The need to revise the methodology of organization of timely training, retraining and advanced training of specialists by integrating theoretical and practical content of training is emphasized. In the process of training it is proposed to use innovative teaching methods, trainings, master classes with the use of information base on existing and future positions of the planned employment. Requirements for wider application in the process of providing knowledge of smart education opportunities, benchmarking technologies, foresight, methods of innovative and strategic games and gaining experience in teamwork are identified. Suggestions for further development of knowledge management system and accumulation of knowledge resources of regions, technologies of formation and mastering of methods of its use and mastering are given, presented in author's realization of target preparation, retraining and advanced training in system of professional training of heads of system of management of regions.

Key words: knowledge resource, formation, accumulation, specialists, managers, management system, socio-economic development, region, knowledge management. 